\title{
MITIGASI BENCANA KEKERINGAN DI KABUPATEN PELALAWAN, RIAU
}

\section{DROUGHT DISASTER MITIGATION IN THE DISTRICT PELALAWAN RIAU}

\author{
Taty Hernaningsih ${ }^{1}$
}

\begin{abstract}
ABSTRAK: Musim kemarau yang berkepanjangan di tahun 2015 ini berimplikasi pada bencana kekeringan di sejumlah wilayah di Indonesia. Kekeringan itu juga melanda propinsi Riau dan kondisi daerahnya dari tahun ke tahun semakin parah karena kemarau panjang. Musim kemarau di bulan Juli 2015, sebanyak 17 kecamatan yang tersebar di enam kabupaten dan kota di tengah Pulau Sumatera itu tidak mengalami hujan selama lebih dari 30 hari. Keadaan ini menyebabkan bencana kekeringan dan berdampak terhadap krisis air di lokasi tersebut serta daerah sekitarnya seperti di kabupaten Pelalawan. Penelitian dilakukan terhadap bencana kekeringan yang terjadi dan mitigasi yang dilakukan untuk mengatasi bencana tersebut yang dapat diterapkan di kabupaten Pelalawan, Riau. Bencana kekeringan yang termasuk klasifikasi kekeringan sosio-ekonomi telah terjadi di kabupaten Pelalawan berupa kekurangan sumber air, kekeringan sumber air sungai dan kekeringan di lahan gambut. Mitigasi untuk mengatasi bencana kekeringan dapat dilakukan dalam jangka panjang maupun jangka pendek. Mitigasi jangka pendek di kawasan Teknopolitan Pelalawan yaitu dengan pembuatan sumur air tanah dalam dengan kedalaman sampai 110 meter. Sedangkan mitigasi jangka panjang di kabupaten tersebut dengan pembangunan sekat kanal. Rekayasa teknologi yang lebih tinggi hingga saat ini belum ada yang bisa diterapkan untuk skala nasional.
\end{abstract}

Kata kunci: bencana kekeringan, kekeringan sosio-ekonomi, mitigasi, sumur air tanah, sekat kanal.

ABSTRACT: A prolonged drought in 2015 has implications for the drought in several regions in Indonesia. The drought has also hit the provinces of Riau and environmental conditions from year to year is getting worse by the drought. In dry season 2015, in July, there was no rain for more than 30 days in 17 districts in six counties and cities in the middle of Sumatera Island. This situation caused by the drought and the impact was on the water crisis in these locations as well as in the surrounding areas of Pelalawan Regency, Riau. Research was conducted on the drought disaster and solutions to overcome the disaster that can be applied in Pelalawan Regency. Drought that can be classified as socio-economic drought has occurred in Pelalawan Regency in the form of water resources shortage, drought of the river water resources and drought in peatlands. Mitigation that can be applied for these drought can be done in long term and short term solutions. Short-term solution in the Teknopolitan Palalawan is by conducting groundwater wells with depths up to 110 meters. The long-term solution in the district is the construction of the canal bulkhead. Advanced engineering technology has not been able to be applied on a national scale.

Keywords: drought disaster, socio-economic drought, mitigation, groundwater well, canal bulkhead. 


\section{PENDAHULUAN}

Kekeringan merupakan salah satu fenomena yang terjadi sebagai dampak penyimpangan iklim global seperti EI Nino dan Osilasi Selatan. Saat ini bencana kekeringan semakin sering terjadi tidak hanya pada periode tahun-tahun EI Nino, tetapi juga pada periode tahun dalam keadaan kondisi normal. Musim kemarau yang berkepanjangan seperti tahun 2015 ini berimplikasi pada bencana kekeringan di sejumlah wilayah di Indonesia. Bahkan, wilayah Bogor, Jawa Barat, yang terkenal dengan sebutan 'kota hujan', tak lepas dari kekeringan.

Bencana kekeringan panjang ini umumnya akan berlangsung hingga akhir November. Badan Nasional Penanggulangan Bencana (BNPB) bahkan telah merilis data bahwa pulau Jawa, Bali, dan Nusa Tenggara diperkirakan akan berada dalam bencana kekeringan akibat kekurangan air hingga puluhan miliar meter kubik. Defisit itu diprediksi tidak akan menurun di tahun-tahun mendatang jika tak ada mitigasi yang tepat terutama krisis air di Jawa, Bali, dan Nusa Tenggara akan menjadi semakin parah dan terus bertambah parah. Pada tahun 2015 seperti yang dilansir dari laman CNN Indonesia, Pulau Jawa dan Bali sebagai dua kawasan dengan populasi terpadat di Indonesia mengalami kekurangan air sebesar 18,79 miliar meter kubik. Sementara itu, Nusa Tenggara mengalami defisit air sebanyak 0,44 miliar meter kubik.

Kekeringan itu juga melanda propinsi Riau dan kondisinya dari tahun ke tahun semakin parah karena kemarau panjang. Pada bulan Juli 2015 yang merupakan musim kemarau, sebanyak 17 kecamatan yang tersebar di enam kabupaten dan kota di tengah Pulau Sumatera itu tidak mengalami hujan selama lebih dari 30 hari. Menurut Sugarin, wilayah kecamatan di Riau yang mengalami kekeringan parah berada di Kabupaten Rokan

1 Pusat Teknologi Lingkungan BPPT

Jl. M. H. Thamrin No.8 Jakarta 10340

email:tatyhernaningsih@gmail.com
Hilir, yaitu Kecamatan Rimba Melintang, Sedinginan, Bangko Pusako, Rantau Kopar, Pujud, dan Ujung Tanjung. Disusul Kecamatan Minas, Tualang, Kerinci Kanan, Sabak Auh, dan Dayun di Kabupaten Siak. Sisanya berada di Kecamatan Kuantan Tengah, Logas Tanah Darat, dan Inuman di Kabupaten Kuantan Singingi, serta Kecamatan Rupat (Bengkalis), Kampar Kiri (Kampar), dan Sungai Sembilan (Dumai) (Rangkuti dan Ichwan, 2015).

Keadaan ini menyebabkan bencana kekeringan dan berdampak terhadap krisis air di lokasi tersebut serta daerah sekitarnya seperti di Kabupaten Pelalawan. Seperti diketahui kebutuhan air adalah urusan vital, semakin banyak jumlah penduduk akan semakin tingggi pula jumlah kebutuhan air. Jika tak diproyeksikan dengan baik, bukan tak mungkin bencana kekeringan akan berubah menjadi bencana mematikan pada beberapa tahun mendatang. Untuk mengatasi permasalahan bencana ini diperlukan mitigasi yang tepat sesuai dengan kondisi daerah, kebiasaan masyarakat maupun kemampuan daerah. Oleh karena itu dalam makalah ini akan dilakukan penelitian terhadap permasalahan kekeringan yang timbul dan dicari cara pemecahan yang mungkin dapat diterapkan di Kabupaten Pelalawan.

\section{METODE}

Penelitian ini dilakukan untuk mengkaji bencana kekeringan yang terjadi di Kabupaten Pelalawan, Riau dan menentukan mitigasi bencana yang dapat diterapkan. Metode penelitian dilakukan dengan mengkaji literatur dan melakukan penelitian lapangan. Dalam penelitian lapangan selain pengamatan kondisi kekeringan, juga dilakukan pemboran dan pengukuran. Pemboran dilakukan dengan alat bor hingga rencana kedalaman 150 meter. Pengukuran kemudian dilakukan adalah dengan well logging pada sumur bor yang telah dibuat. Pengukuran ini dimaksudkan untuk menentukan kedudukan perlapisan batuan pada sumur bor tersebut terutama lapisan pembawa air secara tepat sehingga tidak 
terjadi kesalahan dalam pemasangan saringan (screen). Metode yang dilakukan adalah metode tahanan jenis (resisitivity) dan metoda potensial diri (self potential). Pengukuran ini dilakukan dari dasar lubang bor ke permukaan sumur dengan mempergunakan alat JensenKeck type BD 002.

Metode pengukuran resistivity $(\mathrm{R})$ dan self potential (S.P) adalah sebagai berikut :

\section{a. Tahanan jenis (resistivity)}

Metode ini digunakan untuk mengetahui kedudukan lapisan batuan yang berada di dalam lubang bor berdasarkan harga tahanan jenis setiap lapisan batuan di dalam sumur bor secara langsung, juga digunakan sebagai pembanding bagi pengukuran dengan menggunakan metode lainnya seperti gamma ray dan lain-lain. Hasil pencatatan metode ini untuk lapisan yang sama pada umumnya merupakan kebalikan dari hasil metode gamma, artinya lapisan yang pada umumnya bertahanan jenis tinggi, mempunyai radiasi yang rendah, sedangkan lapisan lempung yang pada umumnya bertahanan jenis rendah mempunyai radiasi gamma yang tinggi. Pada dasarnya metode ini adalah sama dengan cara penyelidikan resistivity di permukaan tanah, perbedaannya terletak pada susunan elektroda-elektroda arus dan potensial dimana pada penampang sumur bor susunan elektroda berada dalam sumur yang terbuka (tidak tertutup pipa casing). Pengukuran dengan metode ini dilakukan dari permukaan ke dasar sumur bor atau sebaliknya. Hasil pengukuran yang digunakan, dilakukan dari dasar ke permukaan sumur bor, karena memberikan hasil yang lebih baik. Satuan yang digunakan pada metoda ini adalah Ohm-meter.

\section{b. Potensial diri atau self potential} (S.P)

Prinsip dari metode ini adalah untuk mengetahui harga potensial yang ditimbulkan oleh batuan itu sendiri. Penyelidikan dengan menggunakan metode ini adalah untuk membedakanakuifer-akuiferyangasin danyang tawar. Hasil pengukuran dengan menggunakan metode ini kemudian dibandingkan dengan hasil pengukuran tahanan jenis. Apabila harga tahanan jenis tinggi sedangkan harga dari petensial diri ini menunjukan kenaikan harga, maka kemungkinan besar akuifer tersebut mengandung kadar $\mathrm{Cl}$ yang tinggi. Jika harga tahanan jenis tinggi dan harga petensial diri menunjukkan penurunan harga, maka akuifer tersebut ditafsirkan sebagai air tawar. Pengukuran dengan metoda ini dilakukan dari dasar ke permukaan sumur bor tanpa casing dengan menggunakan satuan miliVolt.

\section{HASIL DAN PEMBAHASAN}

\subsection{Bencana Kekeringan Air Di Kabupaten Pelalawan}

Kekeringan dapat diklasifikasikan lebih spesifik yaitu kekeringan meteorologis, kekeringan hidrologis, kekeringan pertanian, kekeringan sosial ekonomi dan kekeringan ekologi. Pada penelitian ini yang akan dibahas adalah kekeringan sosial ekonomi. Seperti diketahui kekeringan ini terjadi berhubungan dengan berkurangnya pasokan komoditi yang bernilai ekonomi dari kebutuhan normal sebagai akibat dari terjadinya kekeringan meteorologis, pertanian dan hidrologis. Kekeringan sosio-ekonomi terjadi ketika permintaan untuk sosial-ekonomi yang baik (pembangkit listrik tenaga air, air, tanaman, ternak) melebihi pasokan karena cuaca terkait kekurangan pasokan (Wilhite dan Glanz, 1985). Bencana kekeringan yang terjadi di Kabupaten Pelalawan adalah kekekurangan sumber air, kekeringan sumber air sungai dan kekeringan di lahan gambut.

\subsubsection{Kekurangan Sumber Air Bersih}

Masyarakat Kelurahan Sorek Satu, Kecamatan Pangkalan Kuras, Kabupaten Pelalawan, Riau yang biasanya menggunakan sumber air bersih dari sumur gali, pada musim kemarau kondisi sumber air ini mengalami kekeringan. Penduduk terpaksa mengambil air seadanya untuk memenuhi kebutuhan seharihari seperti yang dapat dilihat pada gambar 1 . Selain itu sumber air sungai juga berkurang 
dan air yang disediakan dari PAM juga tidak mengalir. Untuk memenuhi kebutuhan air penduduk mengambil air dari desa tetangga yang masih terdapat sumber air bersih dan membeli air bersih galon. Pengeluaran untuk membayar air galon pada saat itu sekitar Rp. 70.000 per 1.000 liternya (Farikhin, 2015).

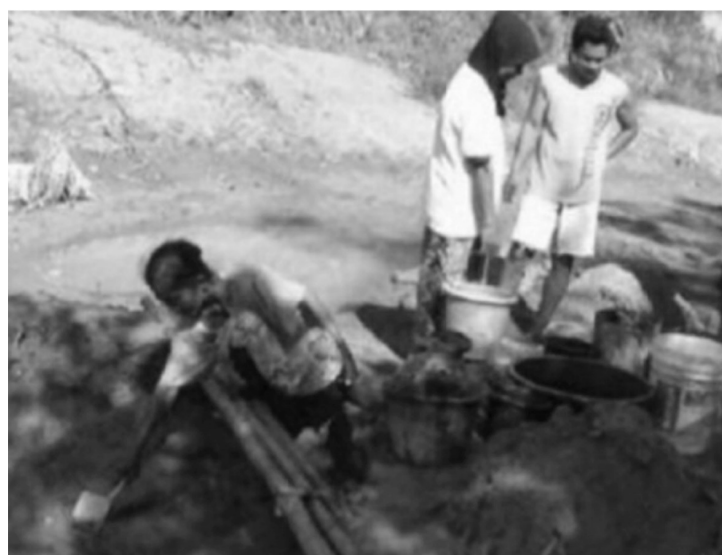

Gambar 1. Kondisi penduduk yang mencari air pada saat kekeringan.

Diantara sumber air yang belum banyak dikembangkan sampai saat ini adalah mengambil sumber air dari air tanah dalam. Oleh karena itu masyarakat tersebut, berharap Pemerintah Daerah (Pemda) membuatkan sumur bor.

\subsubsection{Kekeringan Air Sungai}

Kekeringan yang menyebabkan berkurangnya sumber air sungai untuk keperluan air bersih juga mengakibatkan bencana karena tidak adanya sumber tenaga listrik. Sebagai contoh yang terjadi sungai Kampar yang airnya juga mengalir kekabupaten Pelalawan telah digunakan untuk Pembangkit Listrik Tenaga Air (PLTA) Koto Panjang yang berlokasi di desa Merangin, Rantau Berangin Kecamatan VIII Koto yang berjarak 87 kilometer dari Pekanbaru (Rian, 2015). Pembangkit listrik ini mendapat energi dari air sungai Kampar yang mengalami kelumpuhan tidak dapat beroperasi yang dapat dilihat pada gambar 2. Dalam hal ini debit air yang minim saat ini tak mampu menggerakkan turbin. Akibatnya tidak ada distribusi listrik untuk masayarakat dan ini menyebabkan kerugian yang sangat besar.

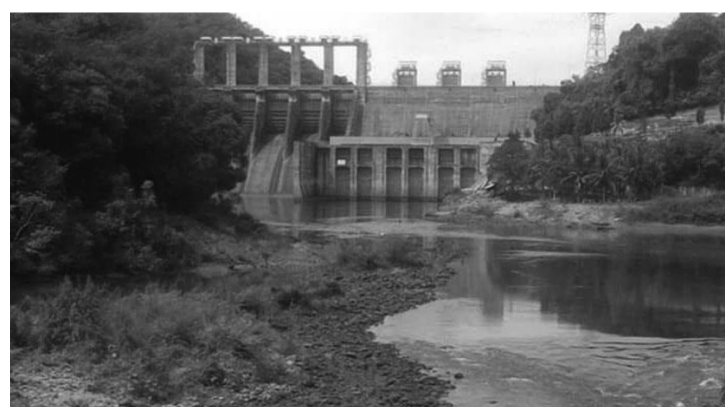

Gambar 2. Pembangkit Listrik Tenaga Air (PLTA) Koto Panjang.

Kepala Bidang Kedaruratan dan Logistik Badan Penanggulangan Bencana Daerah (BPBD) Kampar, Muhammad Nasir menyatakan turbin yang ada pada saat air kurang dari debit minimum mengalami mati total dan kondisi PLTA lumpuh. Kondisi minimum terjadi pada saat ini tinggi elevasi permukaan waduk jauh dari minimum yakni 73,5 meter di atas permukaan laut ( $\mathrm{mdpl}$ ) dan turbin tidak dapat berputar.

\subsubsection{Kekeringan Di Lahan Gambut}

Luas lahan gambut di Riau yang mencapai 4,04 juta hektar adalah lahan gambut terluas di Sumatera. Jumlah itu mencapai 56 persen total lahan gambut di wilayah Sumatera. Namun akibat kekeringan maka kondisinya saat ini lebih dari separuh atau lebih dari $50 \%$ lahan gambut di Riau sudah rusak. Selain kekeringan, kerusakan itu juga disebabkan pembukaan lahan kebun di lahan gambut, pembakaran dan aktivitas masyarakat lainnya. Kekeringan air sungai dan kerusakan lingkungan yang terjadi di desa Ukui, Kabupaten Pelalawan dianggap masyarakat karena adanya alih fungsi lahan menjadi perkebunan kelapa sawit yang dikelola oleh PT. Gandahera Hendana. 
Kepala Sub Bidang Pengendalian Kerusakan Ekosistem Darat BLH, Manipol kepada Riau Pos (Rian, 2015), menjelaskan, bahwa lahan gambut ada dua klasifikasi, yaitu lahan gambut yang masuk di kawasan lindung dan kawasan budidaya. Berdasarkan data kedua klasifikasi lahan gambut ini sudah rusak. Walaupun Badan Lingkungan Hidup (BLH) Provinsi Riau bersama dengan dinas dan instansi terkait di Provinsi Riau selalu menyarankan agar tidak melakukan pengerusakan lahan di areal gambut.

Selain itu, mengikuti pengelolaan lahan gambut sesuai dengan kaidah-kaidah yang diatur Kementerian Lingkungan Hidup RI maupun di Kementerian lainnya. Sementara upaya yang dilakukan adalah melakukan rehabilitasi kawasan gambut dengan melakukan penanaman pohon di kawasan gambut, yang dilakukan bersama dinas terkait dan program dari Kementerian Lingkungan Hidup RI.

Hal ini dimaksudkan agar kerusakan tidak terjadi terlalu parah. Tidak terjadinya kekeringan di lahan gambut dan upaya lain untuk rehabilitasi. Rehabilitasi lahan gambut lebih sulit dibandingkan lahan lainnya.

\subsection{Mitigasi Bencana Kekeringan Air Di Kabupaten Pelalawan Riau}

Mitigasi bencana kekeringan air yang dinilai efektif dapat dilakukan dalam jangka pendek dan jangka panjang. Untuk mengatasi kekeringan dalam jangka pendek adalah memenuhi kebutuhan air masyarakat dengan keterlibatan pemerintah pusat melalui program penyediaan air bersih. Sebelum memenuhi kebutuhan tersebut, diperlukan kegiatan proyeksi dan mengukur kapasitas dan kebutuhan air bersih bagi masyarakat kabupaten Pelalawan.

Sedangkan untuk mengatasi masalah kekeringan pada daerah-daerah rawan dalam jangka panjang, perlu koordinasi lebih intensif dengan instansi lain, salah satunya dengan Dinas Pekerjaan Umum atau Cipta Karya.
Dalam menghadapi kekeringan, pihak BPBD Riau juga perlu ikut serta pada pembenahan sejumlah tanggul sungai yang kondisinya rusak (ACT, 2015). Apalagi, jika musim hujan akan tiba dan adanya potensi banjir dilokasi tersebut. Yang perlu diperhatikan tidak hanya tanggul sungai, tetapi juga saluran dan jalan. Dari inventarisasi, sejauh ini Kabupaten Pelalawan menjadi wilayah dengan jumlah kanal terbanyak.

\subsubsection{Mitigasi Jangka Pendek}

Mitigasi jangka pendek, terkait dengan hal-hal teknis yang dilakukan untuk mengantisipasi sementara masalah kekeringan. Cara paling mudah adalah dengan melakukan distribusi air bersih dengan tangki air, perbaikan pipa, pembuatan sumur bor, pompanisasi, dan pembangunan bak-bak penampungan air hujan yang dibantu oleh instansi yang terkait seperti Kementerian Pekerjaan Umum, Pertanian dan Badan Nasional Penanggulangan Bencana.

Salah satu cara yang dilakukan Pemerintah Daerah Kabupaten Pelalawan yang dilakukan adalah mencari sumber air permukaan atau air tanah. Untuk kawasan Teknopolitan Pelalawan sumber air permukaan jaraknya cukup jauh sehingga mitigasi yang dapat dilakukan untuk jangka pendek yaitu dengan membuat sumur air tanah dalam. Pembuatan sumur air tanah dalam yang telah dilakukan di kawasan Teknopolitan untuk memenuhi kebutuhan Sekolah Tinggi Teknologi Pelalawan (STTP) diharapkan didapat hasil air bersih dengan kualitas baik dengan kapasitas yang mecukupi kebutuhan STTP.

Hasil pengukuran well logging sumur air tanah dalam ini menghasilkan grafik-grafik tahanan jenis dan potensial diri. Penafsiran secara kualitatif dilaksanakan dengan membandingkan hasil pengukuran harga resistivity dan harga potensial diri, kemudian dibandingkan lagi dengan data litologi sumur bor. Hasil penafsiran tersebut dapat dilihat pada tabel 1. 
Tabel 1. Resistivity, Potensial Diri dan Litologi Di STTP Pelalawan.

\begin{tabular}{|c|c|c|l|c|}
\hline \multirow{2}{*}{ Depth } & \multicolumn{2}{|c|}{ Hasil Pengamatan } & \multirow{2}{*}{$\begin{array}{c}\text { Perkiraan } \\
\text { Litologi }\end{array}$} & \multirow{2}{*}{ Keterangan } \\
\cline { 2 - 3 } & SP & \multicolumn{1}{|c|}{ Rho } & \multicolumn{1}{|c|}{} \\
\hline $1-40$ & $921-921$ & $52-52$ & Tanah Penutup & \\
\hline $40-45$ & $920-930$ & $52-92$ & Pasir Tufaan & \\
\hline $45-72$ & $908-928$ & $38-68$ & Lempung & \\
\hline $72-77$ & $907-930$ & $98-148$ & Pasir Tufaan & \\
\hline $77-81$ & $900-901$ & $57-62$ & Lempung & \\
\hline $81-89$ & $908-925$ & $95-152$ & Pasir Tufaan & Akuifer \\
\hline $89-111$ & $885-935$ & $29-52$ & Lempung & \\
\hline $111-117$ & $862-890$ & $79-124$ & Pasir Tufaan & Akuifer \\
\hline $117-121$ & $870-890$ & $31-47$ & Lempung & \\
\hline $121-130$ & $890-899$ & $78-104$ & Pasir Tufaan & Akuifer \\
\hline $130-132$ & $892-892$ & $54-56$ & Lempung & \\
\hline $132-135$ & $889-891$ & $86-95$ & Pasir Tufaan & Akuifer \\
\hline $135-139$ & $879-885$ & $47-72$ & Lempung & \\
\hline $139-150$ & $882-890$ & $92-121$ & Pasir Tufaan & Akuifer \\
\hline
\end{tabular}

Sebagai kesimpulan dari hasil pengukuran well logging dengan menggunakan metode resistivity $(R)$ dan potensial diri (S.P) pada sumur bor ini adalah sebagai berikut:

1. Pengukuran well logging telah memberikan gambaran tentang kedudukan lapisan batuan terutama lapisan akuifer, sehingga didalam pemasangan saringan dapat dilakukan dengan lebih tepat dan teliti.

2. Lapisan akuifer yang dapat disadap adalah pada kedalaman antara 81 - 89 meter, antara 111 - 117 meter, antara 121 - 130 meter, antara 132 - 135 meter, dan antara 139 - 150 meter.

Dari lapisan akuifer tersebut dapat letak saringan pada kedalaman berikut, yaitu:
1) 84.0 - 87.0 meter
2) 114.0 - 117.0 meter
3) 123.0 - 129.0 meter
4) 141.0 - 147.0 meter

Hasil interpretasi kondisi bawah permukaan STTP Pelalawan dapat dilihat pada gambar 3. Pengambilan air tanah dilakukan pada lapisan tanah yang mengandung air pada kedalaman 110 meter.

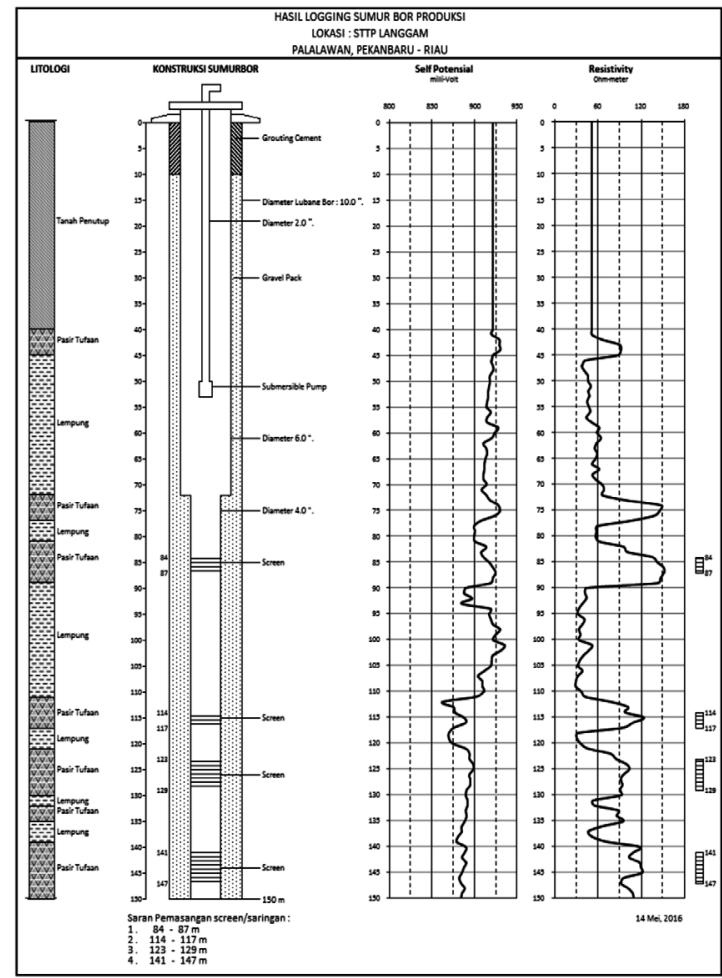

Gambar 3. Hasil Interpretasi Kondisi Bawah Permukaan STTP Pelalawan.

\subsubsection{Mitigasi Jangka Panjang}

Mitigasi jangka panjang banyak tergantung pada kebijakan politik dan penanggulangan bencana yang lebih kompleks. Untuk mitigasi ini dibutuhkan dana yang banyak dan komitmen dari semua pihak baik masyarakat, pemerintah maupun pihakpihak yang terkait. Sehingga pengelolaan kekeringan di lahan gambut harus sesuai dengan kaidah-kaidah yang diatur Kementerian Lingkungan Hidup Republik Indonesia maupun di Kementerian lainnya. Sementara upaya yang dilakukan adalah melakukan rehabilitasi kawasan gambut dengan melakukan penanaman pohon di kawasan gambut, yang dilakukan bersama dinas terkait dan program dari Kementerian Lingkungan Hidup Republik Indonesia. Salah satunya program yang hasilnya kurang tepat adalah mitigasi ini terjadi pada tahun 1989 yaitu pemerintah pusat 
membuat proyek yang bernama Integrated Swamp Development Project (ISDP) atau pembangunan daerah rawa secara menyeluruh yang dibiayai oleh Bank Dunia. Belasan kanal untuk irigasi dan transportasi dibangun membelah desa, memotong kontur tanpa kajian yang tepat. Kanalisasi yang tidak memperhitungkan dampak lingkungan, rentan menyebabkan lahan gambut menjadi kering sehingga sulit menyerap air kembali. Gambut yang mengering itu memiliki karakteristik berbobot ringan, strukturnya lepas-lepas seperti pasir, sulit ditanami tumbuhan, dan mudah terbakar (Suryadiputra, 2005).

Oleh karena itu mitigasi ditujukan agar kerusakan dan kekeringan bisa ditangani dengan baik. Diantara mitigasi tersebut adalah dilakukan dengan pembangunan waduk, pengelolaan Daerah Aliran Sungai, hingga mencakup konservasi tanah dan air. Upaya lain agar tidak terjadinya kekeringan di lahan gambut adalah dengan rehabilitasi. Rehabilitasi lahan gambut lebih sulit dibandingkan lahan lainnya.

Konservasi tanah dan air dapat dilakukan dengan sistem pengelolaan tata air gambut. Salah satu cara dari sistem ini yang telah diterapkan di Kabupaten Pelalawan adalah pembangunan sekat kanal. Pembangunan sekat kanal sudah dilakukan oleh perusahaan kelapa sawit RAPP. Sekat kanal ini merupakan sistem kanal ekohidro ini murah dan mudah serta tidak perlu memerlukan biaya besar. Sejumlah proyek pembangunan sekat kanal ditangani sama dengan proyek infrastruktur lain, semacam pembangunan jalan atau jembatan. Tetapi pada penerapan sekat kanal perlu ada koordinasi dengan lingkungan sekitarnya agar fungsinya optimal.

Pembangunan sekat kanal ini juga merupakan sistem water control. Artinya, pada musim kemarau aliran air dihentikan dan air tetap berada pada kanal jadi dapat menjadi penampung air saat musim kemarau berlangsung. Jika hujan, aliran air dibuka kembali, namun, air tersebut tidak membanjiri daerah masyarakat. Dam dibuat lebih tinggi setengah meter dari kanal. Tujuannya agar dam tidak digenangi air, Pembendungan kanal dapat menaikkan ketinggian air di lahan gambut sehingga mencegah lahan gambut menjadi kering. Penyekatan parit atau saluran dalam hal ini adalah kegiatan-kegiatan yang bertujuan untuk menahan air di dalam parit atau saluran dengan membuat sekat di dalamnya. Sekat ini segera akan dibangun di daerah lainnya seperti di Pulang Pisau.

Untuk melaksanakan kegiatan penyekatan parit atau saluran di suatu lokasi, tipe atau jenis sekat yang akan dipakai sangat tergantung pada kondisi biofisik lapangan yang ada. Namun paling tidak ada 4 jenis sekat yang dapat diusulkan untuk digunakan yaitu sekat papan,sekat dengan bahan pengisi yang dapat dilihat pada gambar 4, sekat plastik dan sekat geser. Berikut ini akan diuraikan sekat dengan bahan pengisi yang banyak digunakan masyarakat yang terdapat pada gambar 4 . Selain itu juga disampaikan teknik pemompaan air dari sungai ke lahan gambut (Suryadiputra, 2005).

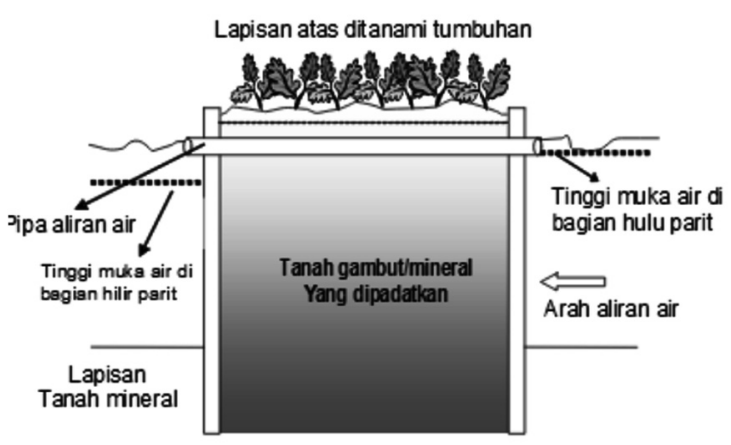

(a) Tampaksamping

Dengan adanya penyekatan saluran atau parit di lahan gambut akan menyebabkan air gambut tidak terlepas ke sungai atau ke lokasi lain disekitarnya sehingga gambut akan tetap dapat dipertahankan sebagai suatu ekosistem lahan basah sebagaimana sifatnya semula. Di Kalimantan Tengah kegiatan penyekatan dikenal pula dengan sebutan menabat (dari kata dasar TABAT), sedangkan di Sumatera disebut menebat (kata dasar TEBAT). Jadi dalam hal ini menyekat parit atau 


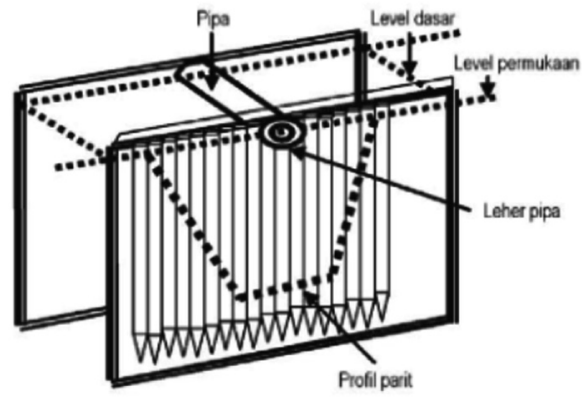

(b) Tampakdepan

Gambar 4. Sekat isi dari bahan papan kayu (Stoneman dan Brooks, 1997).

saluran bukan berarti bahwa seluruh volume parit atau saluran ditimbun kembali.

Dimensi ukuran fisik parit atau saluran (meliputi: panjang, lebar, kedalaman, jarak antar parit) penting diketahui untuk menetapkan jenis dan banyaknya materi/ bahan penyekat yang akan digunakan. Disamping itu, kemiringan lahan juga harus diketahui untuk menentukan berapa banyak jumlah sekat yang akan dibangun pada ruas parit atau saluran. Makin miring atau curam suatu parit atau saluran pada lahan gambut, maka jumlah sekat yang akan dibangun semakin banyak Ada 4 jenis sekat yang dapat diusulkan untuk digunakan yaitu sekat papan, sekat dengan bahan pengisi, sekat plastik dan sekat geser.

Air dalam ekosistem lahan gambut merupakan komponen yang vital. Sehingga pengaturan atau pemberian air pada lahan gambut yang telah dibangun tanggul dalam rangka mencegah kekeringan dapat dilakukan melalui pemompaan seperti yang dilihat pada gambar 5. Pemompaan dapat dilakukan dari suatu reservoir, seperti danau, sungai dan lainlainnya lalu dialirkan ke lahan gambut untuk menaikkan tinggi muka air tanah sesuai yang dikehendaki. Kemudian, tinggi muka air tanah di lahan gambut ini dapat dikendalikan dengan membuat saluran pembuangan atau spillway (berupa parit kecil atau dengan pipa PVC) dan diarahkan ke tempat lain yang letaknya lebih rendah (Stoneman dan Brooks, 1997).

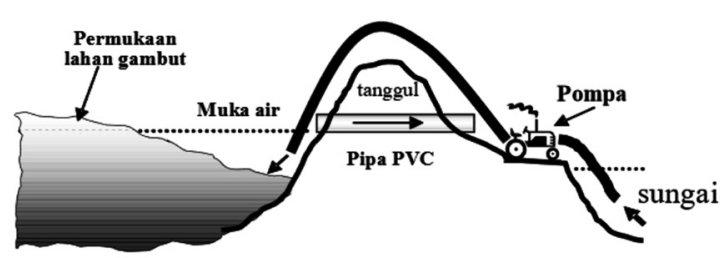

Gambar 5. Pengaturan air pada lahan gambut melalui pemompaan (Stoneman dan Brooks, 1997).

Pembuatan sekat kanal yang terdiri atas tutup saluran-saluran dengan di lahan gambut dapat dilihat pada gambar 6. Peatland Water Management RAPP, berupa sekat kanal yang ditinjau Bupati Pulang Pisau, Provinsi Kalimantan Tengah, H. Edy Pratowo dapat dilihat pada gambar 7 (tribunpekanbaru.com, 2016). Dalam aplikasinya sekat ini kadangkadang tidak optimal manfaatnya karena ada beberapa permasalahan. Sebagai contoh adalah sekat kanal yang berlokasi di Riau, banyak pemegang konsesi lahan yang menahan air di kawasannya, sehingga kanalkanal yang berlokasi di lingkungan masyarakat yang membutuhkan air keadaannya tetap kering.
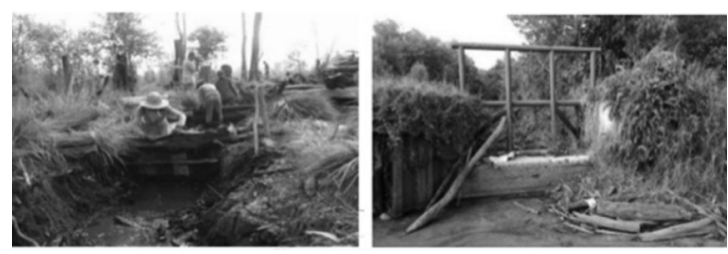

Gambar 6. Tabat/ tutup saluran - saluran di lahan gambut sebelum musim kemarau dan pintu saluran.

Pemerintah dalam hal ini seharusnya juga turut mendorong perusahaan semacam ini untuk berbagi air. Karena tujuan pembuatan sekat kanal adalah membasahi kembali lahan gambut, bukan sekadar membangun dam-dam itu. Karena kalau dam dibangun sementara air tidak ada berarti mitigasi mengatasi kekeringan tidak berhasil. 


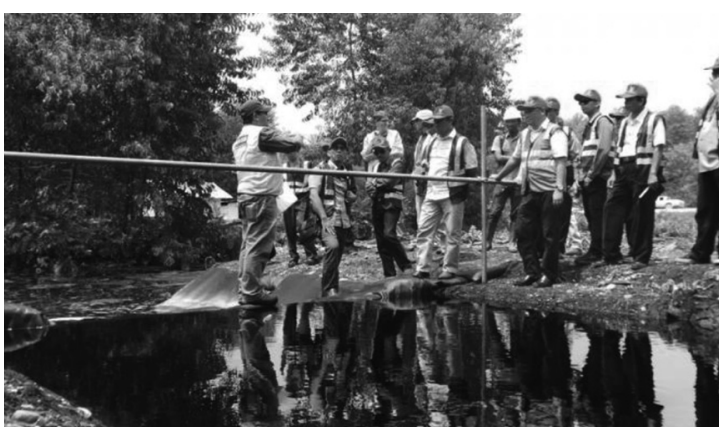

Gambar 7. Peatland Water Management RAPP Pelalawan, berupa sekat kanal ditinjau Bupati Pulang Pisau (tribunpekanbaru.com, 2016).

Dua bentuk mitigasi jangka pendek dan panjang yang dipaparkan di atas setidaknya adalah mitigasi yang saat ini sudah ada cara dan desain teknisnya. Untuk rekayasa teknologi yang lebih tinggi hingga saat ini belum ada ide yang bisa diterapkan untuk skala nasional.

\section{KESIMPULAN}

Bencana kekeringan yang termasuk klasifikasi kekeringan sosio-ekonomi telah terjadi di Kabupaten Pelalawan berupa kekurangan sumber air telah terjadi di desa Sorek, kekeringan sumber air sungai yang menyebabkan Pembangkit Listrik Tenaga Air (PLTA) Koto Panjang tidak beroperasi dan kekeringan di lahan gambut telah menyebabkan lebih dari separuh atau $50 \%$ lahan gambut di Riau sudah rusak.

Mitigasi bencana kekeringan dapat dilakukan dalam jangka panjang maupun jangka pendek. Dalam jangka pendek, mitigasi dilakukan dengan distribusi air bersih memakai tangki air, perbaikan pipa, pembuatan sumur bor, pompanisasi, dan pembangunan bakbak penampungan air hujan. Di kawasan
Teknopolitan Pelalawan telah dilakukan pembuatan sumur air tanah dalam dengan kedalaman sampai 110 meter. Sedangkan mitigasi jangka panjang meliputi pembangunan waduk, pengelolaan Daerah Aliran Sungai, hingga mencakup konservasi tanah dan air. Konservasi tanah dan air yang telah dilakukan di kabupaten Pelalawan dengan pembangunan sekat kanal. Rekayasa teknologi yang lebih tinggi hingga saat ini belum ada yang bisa diterapkan untuk skala nasional.

\section{DAFTAR PUSTAKA}

Rangkuti, Syahnan dan Ichwan Susantom, 2015, Kekeringan, Titik Panas di Riau Meluas, Kompas 23 Juli 2015.

Wilhite, D.A. dan M. H. Glantz, 1985, Understanding the Drought Phenomenon: The Role of Definitions, Water International 10 (3), 111-120.

Farikhin, 2015, Dilanda Kekeringan, Warga Sorek Pelalawan Kesulitan Dapatkan Air Bersih, Pangkalan Kerinci, Riau, goriau. com, diakses 22 September 2015.

Rian, 2015, Kekeringan, PLTA Koto Panjang Lumpuh Total, Wartanesia 10 Oktober 2016.

ACT (Aksi Tanggap Cepat), Care for Humanity, 2015, Menyusun Mitigasi Atasi Bencana Kekeringan, 3 Agustus 2015.

Suryadiputra, I. N, 2005, Panduan Penyekatan Parit dan Saluran di Lahan Gambut Bersama Masyarakat, Wetlands International - Indonesia Programme.

Stoneman, R. dan Brooks, S., 1997, Conserving Bogs: The Management Handbook, The Stationery Office, Edinburgh.

Tribunpekanbaru.com, 2016, Bupati Pulau Pisau Belajar Buat Sekat Kanal Ke Pelalawan, Pangkalan Kerinci, 18 Maret 2016. 